\author{
Alexander B. Sebentsov ${ }^{1,2 *}$ \\ ${ }^{1}$ Institute of Geography, Russian Academy of Sciences, Moscow, Russia \\ ${ }^{2}$ Immanuel Kant Baltic Federal University, Kaliningrad, Russia.
}

*Corresponding author: asebentsov@igras.ru

\title{
CROSS-BORDER COOPERATION ON THE EU-RUSSIAN BORDERS: RESULTS OF THE PROGRAM APPROACH
}

\begin{abstract}
Cooperation across the Russia-EU border has been drawing much attention in recent years. The majority of studies point out programs' efficacy, high density of border institutions and resistance to geopolitical risks among other factors. These advancements can be explained by the theory of multilevel collaboration which implies that diverse and multiple cooperation institutions can effectively distinguish matters of high politics from practical issues concerning interests of those living along the external borders.

The article aims to analyze the impact of cross-border cooperation programs (CBC Programs) on the thematic, institutional and spatial structure of the cross-border relations.

The research is grounded in the overview and analysis of a large volume of empirical data including reports and descriptions of cross-border cooperation programs, data provided by the regional governing agencies, as well as 76 semistructured interviews obtained from regional experts as part of several research expeditions by the Laboratory of Geopolitical Studies of the Institute of Geography RAS taken place over the period from 2011 to 2018.

Main characteristics and long-term trends of the cross-border program approach are examined as follows: growth in governmental coordination on various agency levels aimed at development and implementation of mutually beneficial partnerships, creation of joint program management bodies, development of uniform policies and joint funding sources for projects, and interest in maintaining an equal level of collaboration.

It is revealed that gradual rise of the programs' role in cross-border cooperation in the area contributed to the restructuring of its institutional systems, launching selection process for the existing border institutions (euro-regions, crossborder regional councils, and others), as well as triggering the synergy effect among them and the transborder forms of cooperation.

The main characteristics of spatial partnership structures are identified. These include those consisting of high concentration of project activities taking place within large urban centers along the external borders and those asymmetrical to cross-border interactions. The former is especially pertinent to the Russian side of the border where just a small number of such centers are involved in up to $70-80 \%$ of project activities. Even fewer number of Russian cities initiate their own collaborative projects. A gradual spatial shift of cooperative projects toward the areas immediately proximate to the borders, as well as the decrease in asymmetry of transborder cooperation are identified as the new trends by the author.
\end{abstract}

KEY WORDS: cross-border cooperation, European Neighborhood Policy, CBC Programs, Russian-EU relations, regionalization

CITATION: Alexander B. Sebentsov (2020) Cross-Border Cooperation On The Eu-Russian Borders: Results Of The Program Approach. Geography, Environment, Sustainability, Vol.13, No 1, p. 74-83

DOI-10.24057/2071-9388-2019-136

\section{INTRODUCTION}

In recent years, the experience of cross-border cooperation (CBC) with countries adjoining the Northwest border of Russia has been characterized by innovation and may serve as a model for other border areas of Russia. Over the past two decades, studies of different approaches to cooperation (Mezhevich 2009; Kuzneczov 2004; Sebentsov 2018, Scott 2015) showed that the European experience is utalized on other borders of Russia as well. Despite the noticeable cooling in relations with European neighbors and the EU as a whole, it is on the borders with the European Union where the highest density of various cooperation institutions have been achieved, which allowed L.B. Vardomsky $(2008 ; 2009)$ to identify a special «European» or institutional cooperation type. Institutionalization of CBC in modern Russian and foreign studies is usually viewed as a necessary condition for effective cross-border interactions. A.S. Makarychev (2002) explains this by high «transaction costs» of border actors facing interstate differences in economic and legal regulations, institutional environment, etc. At the same time, numerous studies show that not all institutions are equally effective, and the development of some institutions is often accompanied by the decline of others. Moreover, formal institutions do not always work in the actual trans-border interactions practice, while numerous informal institutions have a great influence on cooperation development.

CBC Programs have become one of the most important institutions of CBC in the last twenty years. Recent studies show that CBC Programs determine the behavior and motivation of most actors of cooperation, and therefore radically change other formats of trans-border interactions (Korneevets et. al. 2010; Scott 2015; Gumenyuk 2018; Sebentsov et. al. 2018).

Thus, the purpose of this article is to show how CBC Programs affect cross-border cooperation with Russia's northwestern neighbors. This article describes a brief analysis of the program approach evolution in the EU neighborhood area, the main trends and patterns of CBC development 
within the programs framework, and the impact of these trends on other institutions and the spatial structure of cooperation.

\section{MATERIALS AND METHODS}

To address study goals, as described by this paper, required a synthesis of considerable material. This included numerous documents describing the regulatory and associated definitions related to CBC content at the border with the EU. Among them, it is necessary to highlight the actual texts of cooperation programs, which made it possible to analyze the evolution of the program approach. Other important sources of information were the reports on the CBC Programs implementation posted on the special internet portal called Knowledge and Expertise in European Programs (KEEP)'. Since different Territorial Cooperation Programs have different capabilities related to work with the data to be supplied to KEEP, the level of completeness and update of the data in KEEP varies considerably from program to program. Therefore, additional data were requested directly from CBC cooperators and associated governmental administrations. The collected materials were then subjected to geocoding, which allowed visualizing the cooperation projects data and their participants; territorial structure and networks of cooperation.

The third set of materials was represented by 66 expert semi-structured interviews, which were collected during expeditions of the laboratory of Geopolitical Studies of the Institute of Geography of the Russian Academy of Sciences from 2011 to 2018 in following regions: Kaliningrad (2011 12 interview, 2014 - 13), Karelia (2014 - 15), Pskov(2015 - 8), Leningrad (2015 - 10), Saint-Petersburg (2018 - 8). Interviews were conducted with representatives of federal, regional and local authorities, public organizations, businessmen, CBC participants and researchers. 10 interviews were conducted with profile departments of Ministry of Foreign Affairs (2018) and Ministry of Transport (2017-2019).

\section{The evolution of the program approach at the borders with the EU}

CBC programs first emerged in Europe. The first prototypes of such programs were several cross-border development plans initiated between 1972 and 1989 within the Euroregion (EUREGIO), located on the border of Germany and the Netherlands (Scott 1993; Perkmann and Sum 2002; Perkmann 2003). Financial support for these plans was provided at the request of EUREGIO by the European Commission, which then took into account the experience gained in the Interreg Program development. The main idea of the new program, launched in 1989, was to support cooperation between different territories within the European communities (Yarovoj 2007). These could be relatively compact border areas (Interreg A, cross-border cooperation), more extensive trans-border areas (Interreg $B$, trans-border cooperation), as well as regions for which immediate proximity was an optional feature (Interreg C, interregional cooperation).

The Interreg launch contributed to the growth of a number of Euroregions in the late 1980s and early 1990s, providing them not only with financial resources but also with proven practices and cooperation formats agreed at the regional, national and supranational levels (Perkmann 2007). Already in 1989, several regulations were adopted that allowed the implementation of Interreg Programs, as well as the use of funds of the European Regional Development Fund (ERDF) not only internally but also with respect to the external borders of the EU (McCall 2015).

For Russia, the experience of CBC became available after Finland and Sweden entered the EU (1995). Interreg IIA «Karelia» (with the participation of the Republic of Karelia) and «Southeast Finland - Russia» (with the Leningrad region and St. Petersburg) were implemented on the Russian Finnish border. Cooperation with the Norwegian and Finnish border regions was carried out within the Barents Region Program framework. The atmosphere of mutual optimism in relations between Russia and European countries was a good background for the development of cross-border cooperation. A concrete manifestation of this was the 1997 Partnership and Cooperation Agreement (PCA), which created a political and legal framework for further cooperation. (The EU - Russia borderland... 2012) Despite high expectations, the actual, fully entitled participation for the Russian side in this program was small (Shlyamin 2002). The federal and regional authorities did not have sufficient resources to support cooperation, and the possibility of financing projects from EU funds was extremely limited (Karelia CBC... 2007).

The first significant funds for $C B C$ were received within the framework of the Tacis CBC Small Project Facility Program which financed 146 projects from 1996 to 2003. A wide range of entities could apply for proposals under this program including regional authorities, local authorities, public institutions (hospitals, schools, universities, museums, nonprofit organizations, etc.). However, despite the presence of a special Regional Support Bureau in St. Petersburg with two offices in Petrozavodsk and Kaliningrad, there was little progress in coordinating with Interreg Programs. (Pooling of financial resources of TACIS... 2001)

In the new program period of 2000-2006, the greatest success in coordination was achieved on the Russian-Finnish border, where, thanks to the Euroregion «Karelia» formed in February 2000, the first joint «Our common border 20012006» Program was prepared in October of the same year based on the Russian «Cross-border cooperation program of the Republic of Karelia, 2001-2006» and the European Interreg IIIA «Karelia» Program. This approach facilitated the identification of common objectives and the creation of a list of common projects. The cooperation results on other parts of the border were much more modest, including with the new EU members (Poland, Lithuania, Estonia, and Latvia), where two new Interreg Programs were also launched.

By 2004, the accumulated interaction experience showed that greater success in implementing joint activities would require better coordination between Tacis and Interreg instruments (Paving the for a New Neighborhood..., 2003; The EU's Eastern Neighbourhood..., 2016). As a result, existing CBC Programs were transformed into Neighborhood Programs. According to the new approach, the programs were to be developed with the participation of regional and local authorities on both sides of the border. Also, the achievement of a higher degree of coordination in project management and the use of various financing instruments was expected. Thus, Russian participants and their European partners had the opportunity to submit joint applications for project financing.

However, there was no unified approach to the review and approval of applications. For European partners, the competition procedures were held at the local managing authority of the Interreg Program, and for Russian participants

${ }^{\prime}$ KEEP is a free database on Territorial Cooperation projects, project partners and programs (including CBC Programs within the scope of the Instrument for Pre-Accession and the European Neighbourhood and Partnership Instrument). It covers the financing periods starting in 2000. The KEEP database is Available at: https://www.keep.eu (Accessed: 31 Aug. 2019) 
- at the European Commission Delegation in Russia, which managed the TACIS Program funds (The KOLARCTIC ENPI... 2007). In addition, numerous inconsistencies between the financial and organizational procedures of the two programs led to persistent funding failures.

The new program period of 2007-2013 brought several significant changes to the cooperation programs. On January 1, 2007, the new European Neighborhood and Partnership Instrument (ENPI) came into effect providing the financial structure for the implementation of the new European Neighborhood Policy. ENPI allowed uniting all internal and external sources of funding from each of the countries in addition to participants' own financial resources. This ensured greater financial procedural uniformity and the timely nature of funding.

The principal changes were also intended to accommodate Russia's earlier reluctance to build relations with the EU within the framework of the European Neighborhood Policy. Instead, Russia had proposed an equal strategic partnership based on four common spaces as an alternative. In addition, Russia expressed its intention to participate in the development and financing of new cooperation programs. In 2009, a package of agreements between the Russian government and the European Union on financing and implementing five new CBC Programs from 2007 to 2013 was signed in Stockholm.

The organization of work needed to implement these programs took into account multilevel management principles, which engaged different levels of authority (supranational, federal, regional and municipal), as well as various actors - direct participants of cooperation. Another innovation was the creation of common governing bodies: the Joint Monitoring Committee (JMC), the Joint Technical Secretariat (JTC) and the Joint Project Selection Committee (JPSC). The JMC included representatives of central, regional and local authorities, and civil society representatives in some cases. Their tasks included development of the content aspects of the program, JTC creation, identification of project selection criteria, creation of the JPSC, and choosing the Joint Managing Authority (JMA). One of the executive power bodies of the EU member state participating in the Program often acted as the JMA. It was in charge for the program implementation, including technical assistance, operational and financial management. This approach made it possible to determine the basic rules of the game in advance by which numerous actors of cooperation were to act.

NUTS $\|$ and NUTS III level provinces and municipalities adjacent to the shared EU borders and constituting the main territory of the programs could participate in the cooperation. Also, the possibility of indirect participation was provided to neighboring regions not adjacent to the border. In practice, the division of the program into the main and adjacent areas meant different opportunities for participation in projects. Only partners from the main program area could count on significant financial resources. In Russia, this formally involved huge areas covering the vast majority of the Northwestern portion of the country, but the border regions constituted its core (Fig. 1). The only exception was the «Kolarctic» Program. Portions of the Swedish, Norwegian and Russian areas (respectively Norrbotten, Troms and Nordland, Arkhangelsk region and Nenets Autonomous Okrug) do not have access to the land border. The explanation for this configuration of the program area is that «Kolarctic» is one of the key financial instruments of cooperation in the Barents Euro-Arctic region.

The development and launch period of new CBC Programs in 2014-2020 coincided with the geopolitical crisis in relations between Russia and its Western partners. Mutual sanctions and the rapid curtailment of bilateral ties between Russia and the EU gave reason to believe that CBC would also be frozen. However, the European Commission adopted a special decision not to apply sanctions to projects implemented under the new programs. After taking into account all the sanctions related risks, Russia also made the decision in favor of further cooperation (Conclusion of The State Duma Committee... 2018). Documents describing the implementation of these programs were agreed upon in December 2015. Intergovernmental agreements on funding and implementation of the programs were signed in 20162017, and the ratification of these agreements by the Russian side was completed by mid-November 2018. As a result, the financial agreements execution between the participants of specific cross-border projects was planned only for 2019, and the period of programs implementation is likely to be extended until 2024

The main innovation of the program period was the funding instrument reform. According to official documents, the European Neighborhood Instrument (ENI) provides for a more rapid and flexible financing of the European Neighborhood Policy, but it is not yet clear how this will specifically affect the work of the programs themselves (Programming of the European Neighborhood... 2013). Another innovation was the transition from multilateral to bilateral cooperation, which was informed by «political challenges» and «poor coordination of projects» by the regional and local authorities of two or more countries (Programming document for EU... 2013). The only exception was the «Kolarctic» Program, where the main cooperation area still covers the territories of four countries at once (The KOLARCTIC ENI CBC... 2015).

It was evident from interviews conducted by the author in 2014 and 2015 that this decision caused different reactions among the developers of new programs. The former developers of the «Estonia-Latvia-Russia» Program assessed the changes neutrally in general, believing that nothing would likely change. In contrast, for the Kaliningrad region, where the large «Poland-Lithuania-Russia» Program was divided into «Poland-Russia» and «Lithuania-Russia» Programs, most of the surveyed experts believed that the state of cooperation would deteriorate. This was predicated on the division of the program, which could lead to the lost opportunity for Russians to unite with one of the European partners for protection of their interests and promoting their objectives.

\section{Evolution of cross-border cooperation within $C B C$ Programs}

Without exception, all CBC Programs were created to reduce costs related to the territory border status. These are their periphery, insufficient level of border infrastructure development, and the «soft security» issues. Other tasks of the Programs were the internal resources search for border region development and common natural and cultural heritage management. Thus, the borderland specifics largely determined the main cooperation directions. From the very beginning, however, the European Commission and Russia's neighboring countries had the pre-emptive right to establish cooperation priority areas.

Under the first TACIS Programs (1996-2003) cooperation was not systematic due to lack of coordination with foreign partners, joint management bodies and common priorities: funding was allocated on a competitive basis, and did not benefit the priorities developed for a specific program 


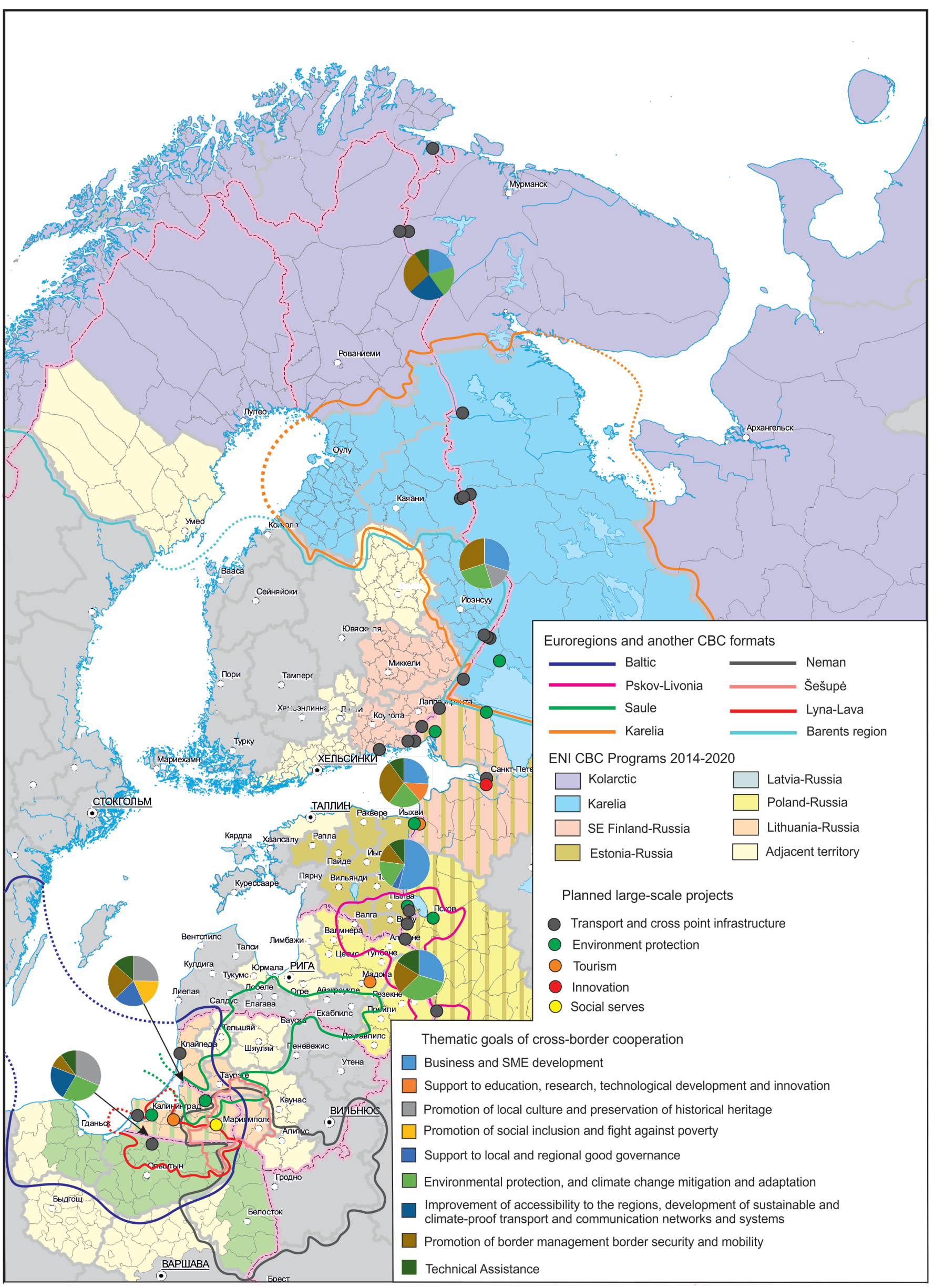

Fig. 1. CBC Programs 2014-2020 and other CBC formats on North-West borders of Russia 
area. Approximately half of the funds were allocated for the infrastructure development, including construction at border crossing points. (Yarovoj and Belokurova 2012). Another 25\% was spent on environmental protection and business support. These were primarily large projects with a budget exceeding 2 million euros. The remaining funds were spent on the realization of a wide variety of «small projects», the main beneficiaries of which were local and regional authorities. The funding amount for such projects was limited to 50 thousand euros, and the main implementation forms were various seminars, international exchanges, internships, and training programs. (Pooling of financial resources of TACIS...2001; TACIS cross-border cooperation... 2001)

In subsequent programs, in which regional and national authorities were more actively involved, cooperation became more systematic and varied in content. It is noted for the period 2004-2006 Russian opportunities to influence the content of TACIS/Interreg Programs were small. However, in 2007, after the start of Russian co-financing of ENPI Programs, federal and regional authorities took a more active position. Detailed CBC programming was carried out in 20072013 by development teams represented mainly by regional authorities (NUTS II territorial level). The European Commission approved the finished Programs, where they were checked for compliance with the priority tasks of the European Neighborhood Policy in the field of CBC.

The program developers had to take into account at least two of the four objectives set by the EU, but could also offer their own, focusing on the territory characteristics. The most popular objectives were those with limited funding, which could have the most visible effect. Thus, the need to solve the periphery problem, which was typical for almost all areas of the program, contributed to the popularity of the first objective which was the promotion of economic and social development within border regions. The second and fourth objectives (solving environmental problems and developing cross-border communications between people) also often became a part of cooperation programs. Only the third objective (ensuring efficient and secure borders) was not included in any of the programs under consideration, as it falls within the exclusive responsibility of central authorities. However, in reality, this objective was indirectly taken into account in all project proposals submitted under the first priority.

Nevertheless, the content side analysis of the implemented projects shows that the interaction trajectories remained the same. Thus, one of the key priorities of cooperation in both program periods was environment protection, which accounted for more than 20\% of funds in TACIS/Interreg Programs of 2004-2006 and in ENPI Programs of 2007-2013. The main cooperation objects were transboundary water basins, where the central problems were related to the discharge of untreated industrial and domestic wastewater into the reservoirs. There were specific problems in the Barents Sea region, where various radiation safety issues proved to be the most immediate concern.

The second direction involved infrastructure development (about 18 and $43 \%$ respectively), including the roads reconstruction, checkpoints construction, street repair in border settlements, etc. For example, on the border with Lithuania, construction of the Panemune-Sovetsk bypass with a bridge over the Neman River was carried out, the Panemune and Kybartai checkpoints were modernized. Similar projects to expand the checkpoints capacity were carried out on other parts of the border.

Much attention was paid to the development of regional and municipal self-government (17.3 and 13.2\%, respectively) which was supposed to be stimulated through cooperation in solving common problems or through joint spatial planning. Thus, on the Russian-Estonian border, the municipalities of Kohtla-Jarve (Estonia) and Slantsy (Leningrad region), which in Soviet times were part of a single complex of the Baltic shale basin, were engaged in the joint development of projects intended for the reconstruction of currently unused industrial facilities and the landscaping of the main city streets. Another example is the joint strategy for the development of twin cities - Finland's Imatra and Russia's Svetogorsk.

Tourism and cultural development projects were of particular importance in some parts of the borders with Finland, Poland and Lithuania. The issues of the common cultural heritage preservation, as well as the cross-border tourism development made such projects a natural priority in the area. Special emphasis in the Program was placed on the joint creation, preparation and development of the technical and economic basis for cross-border tourism products, joint activity on their promotion, classification and certification, as well as tour guide training.

In the 2007-2013 Programs, an important innovation was the so-called large-scale projects (LSP) with an investment component, for which up to $30 \%$ of the total budget could be spent. Their emergence was a response to requests by national and regional authorities, who hoped that large projects would have a more visible impact on the ordinary citizens'lives.

One of the key criteria for the implementation of these projects was geographical - they had to be implemented only in the main territory of the program, create a large-scale effect on the border areas, and have the unconditional support of national and regional authorities. The projects were also to be in compliance with national and regional strategies. The only exception to this rule are the two projects under the Kolarctic Program: reconstruction of the Arkhangelsk airport and the wind park in the Nenets Autonomous Okrug. These project locations are distant from the borders with Finland and the Scandinavian countries, at a distance of over 500 and $1000 \mathrm{~km}$, respectively.

As a result, the vast majority of LSP was related to infrastructure development, which greatly affected the overall cost structure. For example, the Ivangorod-Narva and Pechora-Orava checkpoints were upgraded on the Estonian part of the border. This work included extending and repairing access roads, installation of new x-ray equipment for customs control, and construction of new terminals. Works similar in content and scale were carried out on the borders of Russia with Lithuania (Kybartai-Chernyshevskoye and Panemune-Sovetsk checkpoints) and Finland (SvetogorskImatra, Brusnichnoye-Nuijamaa).

Considerable funds were invested in urban sewage systems in areas where large transboundary water basins cross borders. On the Russian-Latvian and Russian-Estonian borders, the projects were aimed at improving the environmental situation in the Peipsi lake reservoir and protecting the waters of the Narva river basin. As a result, sewage treatment facilities were modernized in several settlements of Estonia, the city of Gdov, and new sewage treatment facilities were built in Pskov. At the Finnish site, the largest was the «Clean Ladoga» project, in which the sewage treatment facilities were built in Sortavala. On the Lithuanian border, the main efforts were focused on improving the environmental situation in the Neman river basin which included construction of a sewage network and sewage treatment facilities in the towns of Neman and Slavsk (Kaliningrad region). Both sewage and water supply networks were developed for the villages of Pakalniškiai and Dumpiai (Klaipeda, Lithuania).

The only LSP in the tourism field in the Program «EstoniaLatvia-Russia» was associated with the development of a 
unique complex of Narva and Ivangorod fortresses as a single object of culture. Parts of the walls and buildings of both fortresses were reconstructed using the allocated 3.4 million euros. This work included improving access for disabled visitors and development of joint tourist routes.

Despite the fact that the new ENI Programs (as mentioned earlier) are only entering the stage of implementation for the first projects in 2019, it is possible to draw our first conclusions about the key cooperation areas of this period. The indicative financial plans analysis shows that the key cooperation topics will lie within border infrastructure development, which will draw about $25 \%$ of all allocated funds, support for entrepreneurship (about 23\%) and environmental protection (about 21\%). The traditional orientation of some segments of the borderland (Russian-Polish, Russian-Finnish, and partly Russian-Estonian) with regard to cooperation in the field of culture and preservation of the shared historical heritage is preserved. Innovation projects became a new phenomenon - it is planned to allocate about 15\% of funds to such projects within the framework of the «South-Eastern Finland - Russia» program.

The trend towards an increase in the value of LSP, which emerged in the previous program period, remains. This is expressed in the direct selection of LSP at the stage of the program creation with the participation of developers and central authorities. Such approach should increase the number of projects implemented directly in the border area, as it is characterized by a special regime of visits and economic activities. Among the projects selected and approved for implementation, most (about 70\%) are related to the transportation and border infrastructure development (e.g. road construction and the checkpoint reconstruction). About $20 \%$ of the projects are related to the resolution of environmental issues and involve construction of sewage systems in Pskov, Vyborg, and other locations. LSP in the field of culture and tourism is planned for the Kaliningrad region (development of a bicycle routes network and water tourism), as well as on the borders with the Baltic countries (development of joint tourist routes).

Thus, the wide participation of various actors in the development of priorities and implementation of concrete projects contributed to the thematic succession of programs. As a result, many projects started in one program period were continued in the next. This, in turn, led to the formation of long-term partner networks and spatial structures of cooperation.

\section{CBC Programs and spatial structure of cross-border cooperation}

The diversity of cooperation institutions is one of the key features of cross-border cooperation's spatial structure, distinguishing this Russian borders' part from others. There are three evolutionary stages of this cooperation in terms of spatial and institutional structure.

At the first stage, which is the period from 1991 to 1995, Russian regions and their neighbors signed numerous bilateral agreements on cross-border, trade and economic cooperation, mainly of a framework nature. In the same period, Intergovernmental Commissions on cross-border cooperation (e.g. with Latvia, Finland and Norway) or special Regional Councils (e.g. with Poland and Lithuania) started being established. Representatives of both regional and national authorities became their members on the basis of intergovernmental agreements. A special Council was established on Estonia's border, which, due to the difficult interstate relations with this country, worked under the regional authorities' auspices and transformed later in Euroregion «Pskov-Livonia». At the «old borders» with Norway,
Poland and Finland, the Intergovernmental Commissions and Councils' main task was to establish checkpoints, discuss conditions of their work, regulate cross-border regime, and elaborate future cooperation's content. At the «new borders», pertinent issues of border delimitation and demarcation were added to these tasks.

At the second stage (from 1996 to 2004), the European Union became a new actor of CBC. Its active participation is manifested in the introduction of new forms and institutions of $\mathrm{CBC}$, which had been already tested on other borders, including internal borders of EU. Additional effect is associated with the already mentioned TACIS border program, which provided these institutions with initial funding for their project activities (Yarovoj and Belokurova 2012). As a result, Euroregions began active development in this period (Fig. 1.). The Kaliningrad region was a pioneer in this matter, since it was literally «doomed» to CBC due to its exclave position, according to N. M. Mezhevich (2009, p.122).

Since 2004, after appearance of new Neighborhood Programs, the third stage of cooperation's spatial and institutional structure development arose. Its distinctive features are growth of coordination between the main actors (regional and national authorities), common program management bodies, coordination of joint priorities, and ensuring a high transparency with regard to competitive and financial procedures. Sustainability and large amounts of funding were especially attractive to Russian participants who could not find such funds within their country. As a result, the actors' rapid reorientation to Neighborhood Programs has had a significant impact on other CBC's formats, triggering selection processes among existing cooperation forms and institutions and also generating synergy effects between them.

Therefore, it can be assumed that the Neighborhood Programs contributed to the decrease in interest by regional and local actors to a whole number of Euroregions, particularly the small ones. Many of them initially had a narrow agenda (mainly environmental focus), and their territory covered only some municipalities in border regions. As a consequence of these features, the necessary financial and organizational resources for these cooperation projects were not provided. For example, the main activities in the Euroregion «Sheshupe» in recent years have been associated with organization of small events to improve the environmental situation in the Scheshupe River, as well as its fishing tournaments. The main project of the «Lyna-Lava» is an annual rafting on the LynaLave River. The Euroregion «Saule» has not held meetings since June 2009. In the Euroregion «Neman», participation of Kaliningrad municipalities is almost imperceptible and is reduced to annual meetings.

On the other hand, the agenda of CBC Programs could be somewhat «narrow» for some of the Euroregions as well. For example, for the Euroregion «Baltic», with territory covering six Baltic countries, Kaliningrad border regional projects are quite local in relation to the goals and objectives.

A completely different situation is seen in the Euroregion «Karelia», that played the role of initiator of program approach in CBC. It participated in promoting its own interests in choosing cooperation priorities, actively using political, organizational and financial capabilities of regional and even national authorities for these purposes. In 2013, «Karelia» started its cooperation on program development for the period of 2014-2020. Later, in 2016, it adopted its own Strategy effectively resulting in the CBC ENI Program Karelia being considered a key financial tool for implementation. (Main Directions of Euregio Karelia... 2014)

An exceptional situation has been developing in the Barents region, where CBC Program «Kolarctic» became an important financial instrument for the Barents Regional 
Council. As a result, this transborder institution shows typical Euroregion features in many areas of its activities. At the same time initially cross-border Program «Kolarctic» has acquired trans-border features. This conclusion is supported by continuing multilateral nature of cooperation, the enormous territory involved in cooperation, as well as considerable distance of many formally «border» projects from land borders.

Accumulating the vast majority of CBC projects, Neighborhood Programs began to determine its spatial structure's main features. First of all, attention should be paid to the high concentration of cooperation projects in main centers of border regions (Fig. 2). The main attraction points are the largest cities and administrative centers and capitals. This situation is seen on both sides of Northwest Russian state border, however, on the Russian side, the level of concentration is noticeably higher. Accordingly, a significantly smaller number of urban centers are involved in cooperation than on the neighbors' side. The absolute record belongs to St. Petersburg which was a partner of more than $70 \%$ of all CBC projects of the «South-East Finland - Russia» Program. The same city, being the most important Northwest center of Russia, attracted a significant part of the projects in other Programs (especially in «Estonia-Latvia-Russia» and «Karelia»).

The role of the administrative center in initiating cooperation projects is even higher. For example, in the first list of projects announced in CBC Program «Karelia» (2014-2020), all Russian projects without exception were initiated by actors from Petrozavodsk.

The capitals also become participants in CBC. In some cases (Finland, the Baltic States), the capitals are situated close to the border area or in adjacent territory of CBC Programs. As a result, they are involved in cross-border interactions (Fig. 2. $B, E)$. Another reason for the participation of capitals in $C B C$ is the involvement of certain central ministries and departments that are responsible for many contacts and projects in the border zone, operating of checkpoints, etc.

In addition, partners from national capitals are often involved as experts in implementing a number of complex technical projects (in the field of construction, environmental protection, etc.). Therefore, in the case of the "Kolarctic», "Karelia», and «SE Finland - Russia» programs, the involvement of capitals in cooperation projects remains noticeable, despite the great distance from the program territory (Fig. 2 A, C, D)

However, CBC has become «more cross-border». This is manifested in the fact that since 2007 CBC Programs are more concerned on border municipalities. As a result, the cooperation has partly shifted from large cities to less successful centers located directly near the border. These became platforms for the above-mentioned LSP (Fig 1, 2).

Another important feature of CBC spatial structure is its asymmetric nature. First of all, this is manifested by the results of CBC Programs that had been and remain much more visible on European partners'side (result asymmetry).
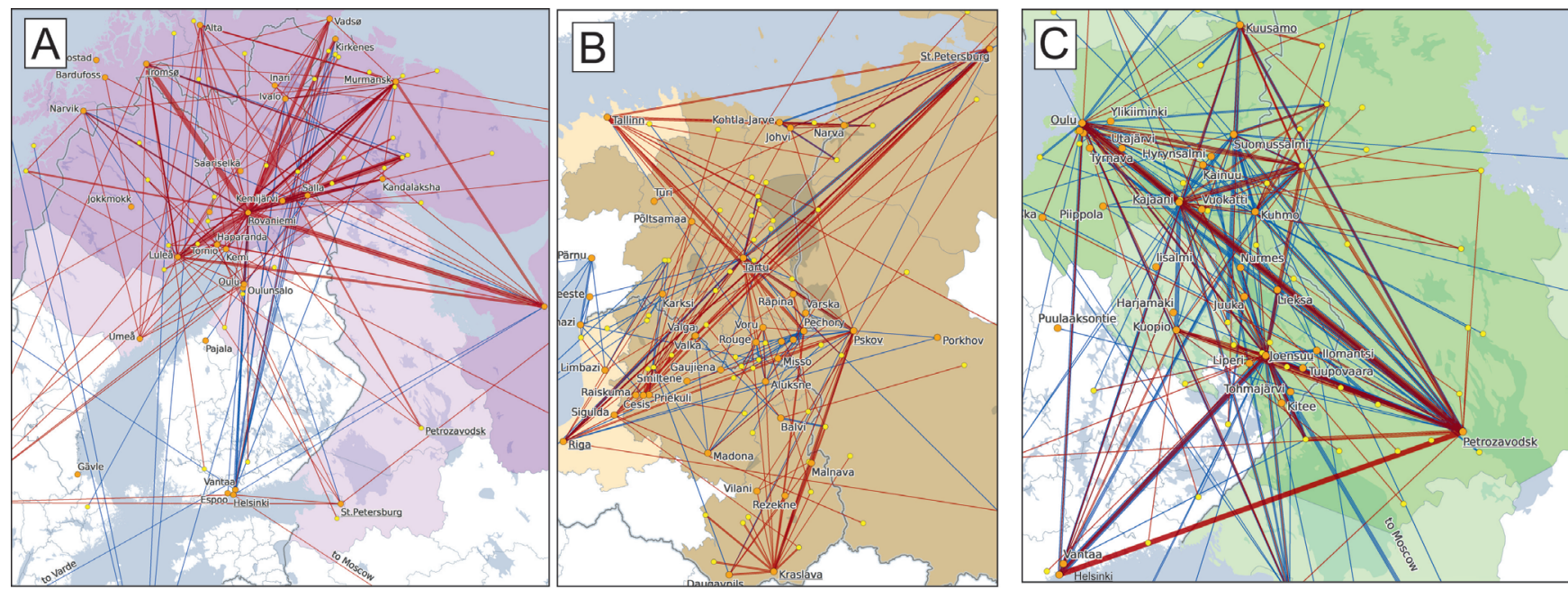

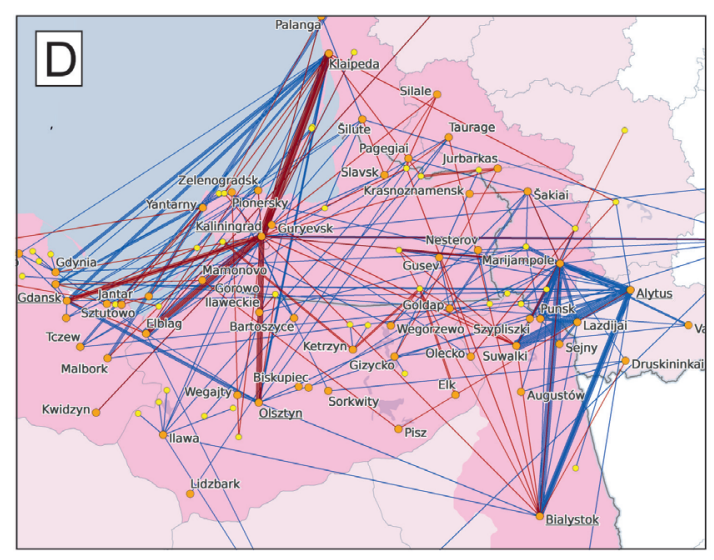

Core Program territories has marked intense colors Adjacent Program territories has marked pale colors

Centers intiated $\mathrm{CBC}$ projects

Centers involved in $\mathrm{CBC}$ projects

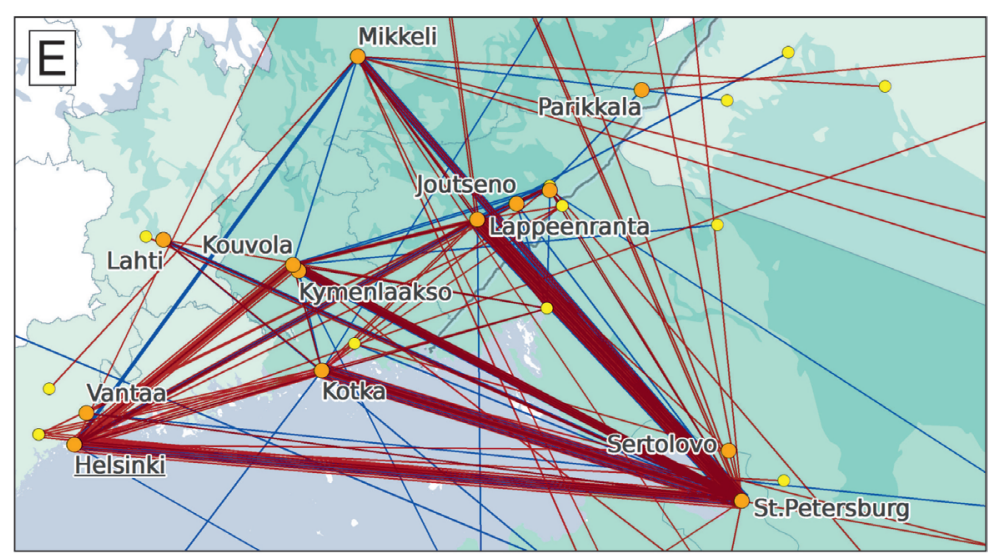

Interaction between partners

TACIS/Interreg CBC Programmes 2000-2006

ENPI CBC Programmes 2007-2013

Fig. 2. Spatial structure of cooperation within the CBC Programs 2000-2013: Kolarcitc - A; Estonia-Latvia-Russia - B; Karelia - C; Lithuania-Poland-Russia - D; South-East Finland - Russia (complied by author using data from KEEP and regional administrations) 
In 2004-2006 program period, an almost unbearable task for the majority of Russian partners was the requirement of co-financing of projects. Currency risks were also a factor. For example, Russian participants could plan their budgets only in rubles, so any jump in the exchange rate became a threat to the project. In addition, unlike European partners, Russian participants did not have supranational and national funding, which further enhanced opportunities' asymmetry (Lithuania-Poland-Russia... 2008).

Another set of serious obstacles for Russian partners was the language barrier, lack of experience in project activities, and lack of knowledge concerning European regulations. These circumstances were significant factors explaining why Russians didn't initiate the project (initiative asymmetry). For example, in case of CBC «Karelia» only Saint Petersburg and Sertolovo could be considered as initiators of cooperation. Eleven cities played the same role in Finish part of the borderland (Fig 2 E).

To be part of the CBC, Russian participants had to look for a «European partner» capable of preparing project documentation and taking on further management. In most cases, financing went through the European partners and they became the project's main beneficiaries. Russians often received small funds or became partners without financial participation. As a result, when building culture centers, roads or sports facilities, European partners received a ready-made project, while Russian partners received a standard design and rough estimate documentation (Sebentsov and Zotova 2018). For some participants interviewed by us (especially in Kaliningrad, Pskov and Leningrad regions), it was the sign of «unequal and asymmetric» cooperation, which was implemented primarily in the interests of neighbors and did not make a serious impact on the Russian regions and its socio-economic state. At the same time, the majority of experts agreed that cooperation can't be equal when the main financial obligations are assumed by the European side.

In 2007-2013 program period, the asymmetry decreased noticeably. This was related to the decision of the Russian Government to take part in co-financing of CBC Programs with the EU. Regional authorities also supported some of the CBC projects initiated by Russian participants. These measures increased Russian participants' opportunities to initiate cooperation. The experience gained by Russian participants in the previous program period also had an impact on increasing their project activity. However, the program still had a number of difficulties related to differences among institutions and legislation between countries. Thus, visa barriers (speed and cost of obtaining visas) were an obstacle for exchanges and seminars. The border regime, which restricts stay of foreigners in the five-kilometer zone along the border, had an impact on the projects in the Russian side of the border zone (Mezhevich 2009). Significant difficulties with interactions between authorities were related to the dissimilar distribution of competences between municipalities, regions and central authorities within the partnering nations. In interviews, foreign participants mentioned that the power structure in Russia was too centralized which led to Russian participants not having the ability to make independent decisions. Weak development of Russian civil society was also called a serious obstacle for cooperation. The small number of Russian NGOs, their isolation from external financial sources and the lack of internal funding made it difficult to find partners. In the financial sector, the major challenges were currency conversion, financial planning and reporting. Changing of these characteristics of institutional environment primarily concerns the Federal authorities' competence. Thus, it can be assumed that despite positive trends, the current features of CBC spatial structure will continue in the medium term.

\section{CONCLUSIONS}

CBC remains one of the most depoliticized areas in relations between Russia and the EU. Its accumulated experience of interaction can be considered as a model for other segments of Russian borders. This became possible due to the use of the program approach, the gradual development of which provided for the development of the agreed set of cooperation priorities, increased coordination of actions between different levels of government on both sides of the border, creation of joint program governance, and the development of unified rules for cooperative projects funding. By the middle of 2000s, such changes had made CBC Programs the most attractive tool for cross-border participants for implementation of their joint projects. This contributed to reformatting of the institutional cooperation structure on the Russian Northwestern borders.

Firstly, Programs launched selection processes for the existing cooperation institutions. Thus, there was a decrease in cooperation intensity in most of Euroregions. Due to their too narrow or too broad agenda, as well as small territorial coverage, some did not have sufficient organizational resources to participate in development of CBC Programs. In fact, only «Karelia» managed to use Russian-Finnish CBC Programs' resources to promote its own priorities and projects.

Secondly, a synergy between CBC institutions became a new force, which led, on the one hand, to this cooperation form's intensification, and, on the other hand, to the reduction of differences between them. This trend is most obvious in the Barents Euro-Arctic region, where activities are increasingly related to cross-border cooperation. CBC Program «Kolarctic», on the contrary, acquired features of trans-border cooperation expressed in the big distance between the program main area and the state borders and also in violation of direct neighborhood principle between the program's participants.

Thirdly, since most CBC projects are implemented within the framework of neighborhood programs, they determine cross-border cooperation spatial structure.

The main feature of $C B C$ spatial structure is high concentration of project activities in the largest cities in the border areas and especially in regional centers. The level of concentration is especially high on the Russian side. That is why a significantly smaller number of centers are involved in cooperation than on the neighbors' part. Nevertheless, since the 2007-2013 program period, there has been a tendency to increase the «cross-border» nature of CBC. As a result, border actors started focusing directly on the border municipalities and small, unsuccessful border settlements. They became platforms for large-scale infrastructure projects, and in most cases aimed at improving transport accessibility of such settlements to the neighboring countries' territories. Another important priority was to reduce the negative impact of these settlements on the ecological status of transboundary river basins.

Another feature of CBC spatial structure is the asymmetry of cross-border interactions. It was also partially compensated by the latest trends of the period 2007-2013. The key factors for increasing the role of Russian participants in these projects were the Federal center's financial contribution to the neighborhood programs, the emergence of joint management bodies and practical cooperation experience gained by Russian participants. As a result, there is an increase in the number of projects initiated by Russian participants andthe number of Russian final beneficiaries is growing. In 2014-2020, about half of the projects were initiated by Russian partners during the application rounds. 
According to interviews with participants of Programs and representatives from regional authorities, opportunities for further CBC are closely related to the Federal border policy's direction. This policy should include defined priorities of project activity and special financial tools for their implementation. Development of such programs within the Eurasian Economic Union could be more preferable, but difficult to implement in the short term.. On the internal Eurasian borders, such programs could be a part of the Eurasian cohesion policy (analogous to the European initiative Interreg), and on the external borders - of the European Neighborhood Policy (analogous to ENI).

\section{ACKNOWLEDGEMENTS}

The research is done as part of the state assignment (theme «Problems and Prospects of Territorial Development of Russia in the Conditions of its Unevenness and Global
Instability» № 0148-2019-0008). The study's field phase, including interviews, in Saint-Petersburg, Leningrad region and Moscow was completed with support of Kone Foundation Project «Northern Dimensions of European Union Actorness. - The Case of Finland and Russia». Mapping and geocoding of CBC Projects were supported by the Russian Academic Excellence Project at the Immanuel Kant Baltic Federal University. The author also expresses gratitude to Stepan Barkov and Anastasia Malakhova - students of Moscow Pedagogical State University, who helped with collecting the data used in this study.

\section{REFERENCES}

Conclusion of The State Duma Committee on International Affairs on the draft Federal Law №. 55057-7 «Ratification of the Agreement on financing and implementation of the Cross-Border Cooperation Program» Russia-Lithuania « for the period 2014-2020» (2018). Database. System of maintenance of legislative activity [online] Available at: www.sozd.duma.gov.ru/ [Accessed 31 Aug. 2019]

ENPI CBC Joint Operational Programme Karelia (2007-2013). Programme Document Approved 19/12/2008 C(2008)8453 (2008) [online] Available at: www.cbcprojects.eu [Accessed 31 Aug. 2019]

Estonia - Latvia - Russia Cross-Border Cooperation Programme Within European Neighbourhood and Partnership Instrument 20072013 (2008). [online] Available at: www.europa.eu/regional_policy/sources/docoffic/official/communic/wider/wider_en [Accessed 31 Aug. 2019].

Gumenyuk I., Kuznetsova T. and Osmolovskaya L. (2016). Local border traffic as an efficient tool for developing cross-border cooperation, Baltic Region, 8(1), 67-82.

Gumenyuk I.S. (2018). Transport topics in cross-border cooperation programs: experience of the Kaliningrad region, Regional studies, 3(61), 84-91 (In Russian).

Karelia CBC. Joint Operational Programme 2014-2020. Programme Document Approved by the European Commission 18.12.2015 (2015). [online] Available at: www.cbcprojects.eu/ [Accessed 31 Aug. 2019].

Kolosov V. A., Klemeshev A.P., Zotova M.V. and Sebentsov A. B. (2015). Russia-European Union borderlands: transboundary gradients, interactions, and current challenges, International Journal of Economics and Social Issues, 5( 2S).

Korneevecz V.S. and Kropinova E.G. (2010). Cross-border cooperation program «Lithuania-Poland-Russia» 2007-2013 and formation of transborder tourist region and ensuring sustainable development of the territory, Bulletin of the Baltic Federal University. I. Kant. Series: Natural and medical Sciences, 7, 152-156 (In Russian).

Kostyukov A.N. and Semakina Yu.A. (2012). Problems of legal regulation of cross-border cooperation, Bulletin of Omsk University. Series «Right», 3, 51-56 (in Russian)

Kuzneczov A.B. (2004). Russian participation in Euroregions, Region of Cooperation. 4 (29). New spatial form of organization of economy, Kaliningrad: KGU, 5-19 (in Russian).

Kuzneczov A.B. (2008). Euroregions: half a century of «small» integration, Contemporary Europe, 2, 48-59 (in Russian).

Lithuania - Poland - Russia Cross-Border Co-Operation Programme 2007-2013 Final Version of Operational Programme after EC Comments. Document adopted by The European Commission on 17 December 2008 (2008). [online] Available at: www.ec.europa.eu/ regional_policy/sources/docoffic/official/communic/wider/wider_en.pdf»[Accessed 31 Aug. 2019].

Lithuania - Russia Cross-Border Cooperation Programme 2014-2020. Approved by European Commission on 19 December 2016 (2016). [online] Available at: www.ec.europa.eu [Accessed 31 Aug. 2019].

Main Directions of Euregio Karelia 2020. Strategic Document of Euregio Karelia. Approved in Kostomuksha on 20th of May 2014. (2014). [online] Available at: www.euregiokarelia.com/en/toimintasuunnitelmat [Accessed 31 Aug. 2019].

Makarychev A.S. (2002). Spatial characteristics of transborder security. In: L.B. Vardomskij and S.V. Golunov, ed, Security and international cooperation in Russia's new border belt, Moscow: Volgograd, 8-40 (in Russian).

McCall C. (2015). State borders in Europe. In: Introduction to Border Studies, Vladivostok: Dalnauka.

Mezhevich N.M. (2009). Cross-border cooperation and practice of Euroregions' activity in the Russian North-West and in the Republic of Belarus: practical experience and legislative support, Saint-Petersburg: Levsha (in Russian).

Radvilavičius Š., Mezhevich N. (2010). The role of cross-border cooperation between The European Union and the Russian Federation in bilateral and regional programmes for economic development. ECO.

Paving the way for a New Neighbourhood: A New Framework for Relations with our Eastern and Southern Neighbours. Communication from the Commission (2003). [online] Available at: www.ec.europa.eu [Accessed 31 Aug. 2019].

Perkmann M. (2003). Cross-border regions in Europe: significance and drivers of regional cross-border co-operation, European Urban \& Regional Studies, 10(2).

Perkmann M. (2007). Construction of New Territorial Scales: A Framework and Case Study of the EUREGIO Cross-border Region, Regional Studies. 2007. 41(2) 253-266.

Perkmann M. and Sum N. (2002). Globalization, regionalization, and cross-border region, Basingstoke: Palgrave Macmillan.

Poland - Russia Cross-Border Cooperation Programme 2014-2020. Approved by European Commission on 19 December 2016 (2016). [online] Available at: www.ec.europa.eu [Accessed 31 Aug. 2019]. 
Pooling of financial resources of TACIS and Interreg Programs (2001) Instruction. Luxemburg: Office for Official Publications of the European Communities (In Russian).

Programming document for EU support to ENI Cross-Border Cooperation. 2014-2020 (2013). Available at: www.ec.europa.eu/ [Accessed 31 Aug. 2019].

Programming of the European Neighbourhood Instrument (ENI) - 2014-2020. (2013). [online] Available at: www.eeas.europa.eu/ [Accessed 31 Aug. 2019].

Scott J.W. (1993) The Institutionalization of Transboundary Cooperation in Europe: Recent Development on the Dutch-German border, Journal of Borderland Studies, VIII(1).

Scott J.W. (2011) Reflections on EU Geopolitics: Consolidation, Neighbourhood and Civil Society in the Reordering of European Space, Geopolitics, 16, 146-175. DOl: 10.1080/14650045.2010.493781.

Scott J.W. (2015) Bordering, Border Politics and Cross-Border Cooperation in Europe. In: Neighbourhood Policy and the Construction of the European External Borders. Cham: Springer., 27-36.

Sebentsov A.B. (2018). Institutional dimension of cross-border cooperation on Russian borders, Regional Studies, 3(66), 66-75.

Sebentsov A.B. and Zotova M.V. (2018). The Kaliningrad Region: Challenges of the exclave position and ways to offset them, The Baltic Region, 10(1), 89-106.

Shlyamin V.A. (2002). Russia in «Northern Dimension», Petrozavodsk: Petrozavodsk State University (In Russian).

South-East Finland - Russia ENPI CBC Programme 2007-2013. Endorsed by the EU Commission on the 12/19/2008 (2008). [online] Available at: www.cbcprojects.eu/ [Accessed 31 Aug. 2019].

South-East Finland - Russia. CBC 2014-2020 Joint Operational Programme. Endorsed by the European Commission on 18 December 2015 C(2015) 9184 (2015). [online] Available at: www.cbcprojects.eu/ [Accessed 31 Aug. 2019].

South-East Finland-Russia Interreg III A/ Neighbourhood Programme 2000-2006. Final report. Approved by the Programme Monitoring Committee on 8 September 2010. (2010). [online] Available at: www.cbcprojects.eu/ [Accessed 31 Aug. 2019].

TACIS cross-border cooperation micro-project assistance program. Instructions for applicants. (2001). World Data Centers. [online] Available at: www.wdcb.ru/grants/rus_guidelines_micro.rtf [Accessed 31 Aug. 2019].

The EU - Russia borderland: new contexts for regional co-operation (2012). ed. by Heikki Eskelinen, Ilkka Liikanen and James W. Scott. London; New York: Routledge.

The EU's eastern neighbourhood: migration, borders and regional stability (2016). edited by Ilkka Liikanen, James W. Scott and Tiina Sotkasiira [et al.]. London, New York: Routledge.

The KOLARCTIC ENI CBC Programme. 2014-2020. Programme Document Approved by the European Commission 18.12.2015 C(2015)9190 (2015). [online] Available at: www.cbcprojects.eu/ [Accessed 31 Aug. 2019].

The KOLARCTIC ENPI CBC Programme. 2007-2013. Programme Document Approved 19/12/2008 C(2008)8453 (2008). [online] Available at: www.cbcprojects.eu/ [Accessed 31 Aug. 2019].

Vardomskij L.B. (2008). Cross-border cooperation at the «new and old» borders of Russia, Eurasian Economic Integration, 1, 3-16 (in Russian).

Vardomskij L.B. (2009). Russian borders in conditions of globalization. Moscow: LIBRCOM (in Russian).

Yarovoj G.O. (2007). Regionalism and cross-border cooperation in Europe (in Russian) Saint-Petersburg: Norma (in Russian).

Yarovoj G.O. and Belokurova E.V. (2012). European Union for regions: what Russian regions coi and should know about the EU, SaintPetersburg: Norma (in Russian). 